\title{
TOBACCO USE AMONG YOUTH: FINDINGS FROM THE GLOBAL YOUTH TOBACCO SURVEY IN MONTENEGRO
}

\author{
Agima LJALJEVIĆ ${ }^{1}$, Elvir ZVRKO², and Marija STOJILJKOVIĆ ${ }^{1}$ \\ Institute of Public Health ${ }^{1}$, Clinic for Otorhinolaryngology and Maxillofacial Surgery, \\ Clinical Center of Montenegro ${ }^{2}$, Podgorica, Montenegro \\ Received in April 2008 \\ Accepted in June 2008
}

\begin{abstract}
Smoking is a burning healthcare and economy issue, especially in underdeveloped countries. The aim of this study was to determine the number of smokers among elementary school students in Montenegro and to assess the correlates of tobacco use. The study was done in 2003 using the World Health Organization Global Youth Tobacco Survey. Our data showed that children as young as ten years smoked. There were $3.6 \%$ permanent smokers and one in three students (30.6\%) experimented with smoking. More than two thirds who smoked agreed that they should quit smoking, and three fourths tried to quit. This study has also shown that children talk too little about smoking in schools and are exposed to passive smoking at home and elsewhere. Activities to solve the elementary school smoking problem should include preventive programs to be introduced into regular school curricula because this is the only way to address the issue properly. In addition, legislation prohibiting indoor tobacco smoking should be implemented rigorously to protect children from passive smoking in public places.
\end{abstract}

KEY WORDS: children, school, smoking

Tobacco use is one of the leading preventable causes of premature death, disease, and disability around the world (1). Nearly five million deaths every year can be attributed to tobacco use, and many more suffer from smoking-related morbidity, while the number of fatalities is expected to more than double by the year 2020, if the current epidemic continues. More than $70 \%$ of these deaths are expected to occur in developing countries (2).

Tobacco smoking in Montenegro creates huge healthcare and economic problems. This has raised the need to determine the number of tobacco smokers, especially among children and young people. In 1999, we conducted a study about the behaviour of young people with UNICEF which showed that $3.4 \%$ elementary school and $19.7 \%$ secondary school students in Montenegro smoked (3).
The Global Youth Tobacco Survey (GYTS), as a part of the Global Tobacco Surveillance System (GTSS) initiated by the World Health Organization (WHO), the Centers for Disease Control and Prevention (CDC), and the Canadian Public Health Association (CPHA) was developed in 1988 with an aim to monitor tobacco use, elicit attitudes about tobacco, and obtain information on exposure to tobacco smoke among the youth (4). Since 1999, GYTS has been conducted in 140 countries (5).

In this framework, in 2003 we conducted a survey of tobacco use among Montenegrin elementary school students of the sixth, seventh, and eighth grade (age range about 13 to 15 years) with the aim to determine the number of smokers and to assess the correlates of tobacco use. 


\section{SUBJECTS AND METHODS}

GYTS is usually carried out among students of the sixth, seventh, and eighth grade of elementary school and the first secondary school grade. It basic features are:

- Intended for students aged 13 to 15 years

- Can include public and private schools

- A two stage stratified random sampling method is used to select a representative sample of students.

- All students in selected classes eligible for participation

- Anonymous and confidential self-administered questionnaire

- Countries may add questions to the questionnaire

- Computer-scannable answer sheets

- Require only 30 to 40 minutes to administer

- Fieldwork conducted in 6 to 8 weeks

- Country-level data with regional-level stratification possible

- Core questionnaire (standard set of survey questions used in all locations).

The 2003 GYTS in Montenegro was conducted by the Institute of Public Health in collaboration with the Ministry of Health and the Ministry of Education on a representative sample of elementary school students. The Ministry of Education provided a database of schools with the number of students in every class, and we forwarded this database to the CDC. The standard GYTS sampling methodology uses a twostage cluster sample design that produces samples of students in grades associated with an age range of 13 to 15 years $(6,7)$. A total of 25 schools were selected to obtain a sample that would produce representative, independent, cross-sectional estimates. In the first stage, schools were selected in proportion to the number of students enrolled in grades 6 to 8 . In the second stage, classes were selected at random, three to five for each of the 25 selected schools. All students in the selected classes attending the school on the day of the survey were eligible to participate.

The survey was anonymous and voluntary. All participants obtained parental consent and none refused to take part in the survey. The survey was conducted using a questionnaire sent from Atlanta, $\mathrm{GA}$, translated into Montenegrin and expanded with specifics such as the most common cigarette brand and pack price. Other questions covered student smoking and willingness to quit, student awareness/ opinion of the smoking issues, tobacco advertising, tobacco availability to young people, environmental exposure, and preventive educational programmes. Before the questionnaire was distributed to schools, it was timed, and the timing showed that it would take no longer than one school hour (45 minutes) to complete it. The questionnaire was completed during class under the supervision of a teacher and field workers trained for this project.

The total number elementary school students in Montenegro is about 30000. Of 2282 in selected classes, 2090 completed the GYTS. School response rate was $100 \%$, while the student response rate was $91.59 \%$.

Students' responses on standardised answer sheets were sent to the Centers for Disease Control and Prevention for further processing, where they were digitalised and tables returned to the coordinator for analysis.

SUDAAN, a software package for statistical analysis of correlated data, was used to calculate weighted prevalence estimates and standard errors (SE) of the estimates $(95 \%$ confidence intervals $[\mathrm{Cl}]$ were calculated from SEs). Differences were considered statistically significant at the $p<0.05$ level (8) The specific test was not done if number of registered cases was lower than 35 .

\section{RESULTS}

The results show that one in three students (30.6\%) has experimented with smoking, and more than a half of those who tried smoking smoked before reaching ten years of age (56.8\%). In this early smoking group, there were significantly more boys.

Our results also show that there are 3.6\% permanent smokers, more boys than girls, and among them $(87.0 \pm 7.9) \%$ use manufactured cigarettes, as opposed to hand-rolled $(24.5 \pm 13.2) \%$ (Table 1).

Nearly one in ten smoking students feels an urge to smoke in the morning, and one in seven non-smokers believes that they will start smoking next year, with no significant difference between boys and girls (Table 2). For both genders the proportion of never smokers being susceptible to initiate smoking ( $15.2 \%$ for both genders) was higher than the current smoking rate.

Almost half of the students reported having been taught in school about the dangers of tobacco during the preceding school year. There were no differences in answers between boys and girls (Table 3). Only 
Tried smoking / \%

\begin{tabular}{lccc} 
& Permanent smokers / \% & $\begin{array}{c}\text { at least once } \\
\text { (experimented) }\end{array}$ & $\begin{array}{c}\text { for the first time } \\
\text { before the age of } 10 \\
\text { years }\end{array}$ \\
\hline Pooled data $(\mathrm{N}=2090)$ & $3.6 \pm 1.9$ & $30.6 \pm 4.8$ & $56.8 \pm 9.6$ \\
Boys & $3.7 \pm 1.9$ & $34.8 \pm 4.4$ & $61.7 \pm 11.0$ \\
Girls & $3.4 \pm 2.1$ & $26.5 \pm 5.5$ & $49.6 \pm 10.8$ \\
\hline
\end{tabular}

Table 2 Elementary school students who are addicted to smoking

\begin{tabular}{lcc}
\hline & $\begin{array}{c}\text { Students who feel the need for } \\
\text { cigarettes in mornings / \% }\end{array}$ & $\begin{array}{c}\text { Students who think they will start } \\
\text { smoking next year / \% }\end{array}$ \\
\hline Pooled data $(\mathrm{N}=2090)$ & $9.1 \pm 6.5$ & $15.2 \pm 1.5$ \\
Boys & $*$ & $15.3 \pm 3.2$ \\
Girls & $*$ & $14.5 \pm 2.3$ \\
\hline
\end{tabular}

* less than 35 cases (statistic tests were not performed)

Table 3 How is the smoking issue addressed in Montenegrin schools

\begin{tabular}{lccc}
\hline & \multicolumn{3}{c}{ The students who reported having been taught in school about / \% } \\
the dangers of tobacco & $\begin{array}{c}\text { health effects of } \\
\text { smoking }\end{array}$ & $\begin{array}{c}\text { the reasons for } \\
\text { starting smoking }\end{array}$ \\
\hline Pooled data $(\mathrm{N}=2090)$ & $47.4 \pm 6.4$ & $41.9 \pm 3.9$ & $36.1 \pm 4.9$ \\
Boys & $47.4 \pm 6.0$ & $43.8 \pm 4.5$ & $34.5 \pm 5.5$ \\
Girls & $47.3 \pm 7.7$ & $40.3 \pm 5.9$ & $37.5 \pm 6.0$ \\
\hline
\end{tabular}

$42 \%$ of students reported having learnt that smoking is harmful to their health (Table 3).

Eight in ten elementary school students who smoked told they wanted to quit smoking, while $78.2 \%$ among them already tried to quit smoking. Again, there were no differences in answers between boys and girls.

Nearly all elementary school students who had never smoked (94.6\%), as well as smokers (98.6\%) stated that they were constantly exposed to tobacco smoke regardless of the sex. More than half the smokers and non-smokers was exposed to tobacco smoke at home due to parental smoking and to a lower extent due to sibling smoking. Speaking of the latter, sisters are significantly more often recognised as "air polluters" than brothers (Table 4).

As for passive smoking, Table 4 shows quite expectedly that student smokers are significantly more exposed to a friend's smoking than non-smokers. However, no differences were found between them in the exposure to the smoking of house guests (Table 4).

Eight in ten elementary school non-smoking students $(81.7 \%)$ and almost all smoking students $(93.7 \%)$ had been exposed to passive smoking in public places. Most non-smokers (92.7 \%) and $55.2 \%$ of smokers believe that smoking should be banned from public places. Half the students nonsmokers and $22.3 \%$ of smokers think that exposure to passive smoking is dangerous for their health (Table 5).

\section{DISCUSSION}

Smoking is not a problem specific for our region. It seems to be very similar worldwide. Globally, about 
Table 4 Exposure to passive smoking at home

\begin{tabular}{|c|c|c|c|c|}
\hline & & $\begin{array}{l}\text { Pooled data } \\
(\mathrm{N}=2090)\end{array}$ & Boys & Girls \\
\hline \multirow{2}{*}{$\begin{array}{l}\text { Exposure to passive } \\
\text { smoking at home / } \%\end{array}$} & Non-smokers & $94.2 \pm 1.5$ & $92.3 \pm 2.4$ & $96.7 \pm 1.5$ \\
\hline & Smokers & $98.6 \pm 2.8$ & $*$ & $*$ \\
\hline \multirow{2}{*}{$\begin{array}{l}\text { Exposure to passive } \\
\text { smoking because of } \\
\text { father smoking / \% }\end{array}$} & Non-smokers & $59.2 \pm 4.4$ & $56.2 \pm 6.5$ & $60.6 \pm 5.5$ \\
\hline & Smokers & $64.5 \pm 11.9$ & $*$ & $*$ \\
\hline \multirow{2}{*}{$\begin{array}{l}\text { Exposure to passive } \\
\text { smoking because of } \\
\text { mother smoking / \% }\end{array}$} & Non-smokers & $48.6 \pm 3.9$ & $44.8 \pm 5.7$ & $51.5 \pm 4.1$ \\
\hline & Smokers & $62.5 \pm 12.2$ & $*$ & * \\
\hline \multirow{2}{*}{$\begin{array}{l}\text { Exposure to passive } \\
\text { smoking because } \\
\text { of siblings (brother/ } \\
\text { sister) smoking / \% }\end{array}$} & Non-smokers & $11.7 \pm 2.0$ & $10.2 \pm 2.5$ & $12.8 \pm 2.3$ \\
\hline & Smokers & $38.4 \pm 10.6$ & $*$ & $*$ \\
\hline \multirow{2}{*}{$\begin{array}{l}\text { Exposure to passive } \\
\text { smoking because of } \\
\text { best friend smoking } \\
1 \%\end{array}$} & Non-smokers & $22.0 \pm 4.1$ & $23.5 \pm 3.9$ & $20.0 \pm 5.4$ \\
\hline & Smokers & $59.4 \pm 11.9$ & $*$ & $*$ \\
\hline \multirow{2}{*}{$\begin{array}{l}\text { Exposure to passive } \\
\text { smoking because of } \\
\text { guests smoking / \% }\end{array}$} & Non-smokers & $90.8 \pm 1.9$ & $89.4 \pm 3.6$ & $93.0 \pm 2.3$ \\
\hline & Smokers & $95.6 \pm 2.7$ & $*$ & $*$ \\
\hline
\end{tabular}

* <35 cases in denominator (statistic tests were not performed)

$80,000-100,000$ young people start smoking every day, and most of them are from the developing countries (9).

The Global Youth Tobacco Survey (GYTS) seeks to establish tobacco use and related determinants in young people (13 to 15 years) all over the world, and we used it to estimate the prevalence of tobacco use in Montenegrin children and get data comparable with other GYTS reports (10). Our study is one of the first comprehensive evaluations of the problem of smoking among adolescent students in Montenegro.

Our data show that $3.9 \% 6,7$, and 8 grade students smoke every day, while every third student has experimented with smoking. It is important to note the prevalence is low compared to some other countries in Europe. A GYTS survey in the Netherlands showed that $5.7 \%$ to $9.7 \%$ of students aged 12 to 15 years smoke every day and almost the half smokes more than 10 cigarettes a day (11). A GYTS survey in Serbia showed that $16.3 \%$ of schoolchildren aged 13 to 15 were permanent smokers (12). GYTS survey conducted in Croatia in 2002 showed that $59.9 \%$ of pupils had tried to smoke or experimented with cigarettes (12). Lower prevalence among our students may be explained by differences in socio-cultural milieu between these populations because there are no heavy taxes, massive information campaigns or strict implementation of law about tobacco control in Montenegro.

Most student smokers used manufactured cigarettes, but there is a new tendency today to use other tobacco products as well.

It is alarming that one in ten permanent smokers feels a strong need to smoke as soon as they wake up, because this is a sign of addiction and an indicator that they might continue to smoke for the rest of their lives. Furthermore, one in seven non-smokers believes that they will start smoking within a year's 
Table 5 Exposure to passive smoking in public places

\begin{tabular}{|c|c|c|c|c|c|c|}
\hline & \multicolumn{2}{|c|}{$\begin{array}{c}\text { Exposure to passive } \\
\text { smoking in public places / } \%\end{array}$} & \multicolumn{2}{|c|}{$\begin{array}{l}\text { Students who support } \\
\text { smoking ban in public } \\
\text { places by law / \% }\end{array}$} & \multicolumn{2}{|c|}{$\begin{array}{l}\text { Students who believe } \\
\text { passive smoking is } \\
\text { dangerous to health / \% }\end{array}$} \\
\hline & $\begin{array}{c}\text { Non- } \\
\text { smokers }\end{array}$ & Smokers & $\begin{array}{c}\text { Non- } \\
\text { smokers }\end{array}$ & Smokers & $\begin{array}{c}\text { Non- } \\
\text { smokers }\end{array}$ & Smokers \\
\hline $\begin{array}{l}\text { Pooled data } \\
(\mathrm{N}=2090)\end{array}$ & $81.7 \pm 1.6$ & $93.9 \pm 6.4$ & $92.7 \pm 2.0$ & $55.2 \pm 14.4$ & $50.2 \pm 2.8$ & $22.3 \pm 10.1$ \\
\hline Boys & $80.1 \pm 2.4$ & $*$ & $93.1 \pm 3.1$ & $*$ & $51.8 \pm 4.8$ & $*$ \\
\hline Girls & $83.7 \pm 3.1$ & $*$ & $92.9 \pm 2.4$ & $*$ & $49.8 \pm 4.5$ & $*$ \\
\hline
\end{tabular}

* <35 cases in denominator (statistic tests were not performed)

time and the proportion of never smokers being susceptible to initiate smoking was higher than the current smoking rate. This possibly suggesting that adolescents smoking rates are likely to increase in the next few years and indicates to evident problem with potential smokers.

Preventive programs significantly influence young people and their behaviour. Some authors point out that parents, teachers, peers and media can greatly contribute to the prevention of smoking among 10 to 15-year-old children (13). This survey has shown that at school children talk little about the smoking issue and about the reasons why they start smoking. The results indicate a definite need for including tobacco related information in the school curriculum.

Besides, elementary school students in our study have shown intention to quit smoking and some have already tried to change their behaviour. It is therefore crucial to help them carry this through by showing them a number of feasible ways to quit smoking.

An important finding was the very high percentage of students being exposed to second-hand smoke in both their home as well as in public places. Children are exposed to passive smoking at home due to unscrupulous behaviour of their parents, who use tobacco products in their presence. Neither is negligible their exposure to passive smoking because of their smoking peers and house guests. Exposure to passive smoking in other countries ranges from $69 \%$ in Bulgaria to 97 \% in Serbia (12).

Our children are exposed to tobacco smoke in public places, and smokers are significantly more exposed than non-smokers. That is understandable because smokers spend lot of time in the company with other smokers and in places where smoking is allowed. Another difference between smokers and non-smokers is in recognising the negative effects of passive smoking on health, even though only a small number of non-smokers among children find passive smoking dangerous for health. It is surprising how few non-smoking students support smoking ban in public places.

Data from our GYTS together with other facts have prioritised the smoking issue, and the Government of Montenegro has defined adequate activities to address it. To reduce the number of smokers several laws limiting the use of tobacco products and a strategy for smoking control have been adopted in accordance with European policies, Montenegro has joined the Stability Pact Project on tobacco control, and a number of economical, legal and prevalence studies and many other activities have been carried out since.

A number of limitations of our study need to be acknowledged. Our survey was cross-sectional, and smoking was self-reported, which means that tobacco use may have been underreported, especially among girls, as it may be treated as a taboo in this population.

\section{CONCLUSION}

Montenegrin elementary schools seem to fail to make their students aware of the health effects of smoking, and the problem of smoking among elementary school students is widespread. In addition, children are constantly exposed to passive smoking with its own significant health risks. Yet, it is the schools which are the right places for preventive action and more effort should be done to define and implement educational programmes that would 
make the children aware of the effects of smoking on health. One of the very important preventive measures against smoking is the current law limiting the use of tobacco products.

\section{REFERENCES}

1. Ezzati M, Lopez AD, Rodgers A, Vander Hoorn S, Murray CJL; The Comparative Risk Assessment Collaborating Group. Selected major risk factors and global and regional burden of disease. Lancet 2002;360:134760.

2. Peto R, Lopez AD, Boreham J, Thun M, Heath C Jr. Mortality from smoking in developed countries 1950-2000: indirect estimation from National Vital Statistics. Oxford: Oxford University Press; 1994.

3. Laušević $D$, Mugoša B, Ljaljević A. Istraživanje stavova i ponašanja školske djece i omladine o bolestima zavisnosti, seksualnosti i ishrani u republici Crnoj Gori [The survey of attitude and behavior of school children and youth about addiction disease, sexuality and nutrition in Montenegro; in Montenegrin]. Podgorica: Institute of public health; 1999.

4. Global Youth Tobacco Survey Collaborating Group. Differences in worldwide tobacco use by gender: findings from the Global Youth Tobacco Survey. J School Health 2003;73:207-15.

5. Warren CW, Jones NR, Peruga A, Chauvin J, Baptiste JP, Costa de Silva V, el Awa F, Tsouros A, Rahman K, Fishburn B, Bettcher DW, Asma S. Global youth tobacco surveillance, 2000-2007. MMWR Surveill Summ 2008;57:1-28.

6. Global Tobacco Surveillance System Collaborating Group (GTSS). Global Tobacco Surveillance System (GTSS): purpose, production, and potential. J School Health 2005;75:15-24.

7. Global Tobacco Surveillance System Collaborative Group (GTSS). The global tobacco surveillance system. Tob Control 2006;15(Suppl 2):ii1-3.

8. Shah BV, Barnwell BG, Bieler GS. Software for the statistical analysis of correlated data (SUDAAN). In User's manual, release 7.5, 1997 [software documentation] Research Triangle Park (NC): Research Triangle Institute; 1997.

9. World Health Organization (WHO). A Policy Framework for Tobacco Control. New Delhi: Regional office for South East Asia, World Health Organization; 2000.

10. Center for Disease Control and Prevention, Global Youth Tobacco Survey. [displayed 20 November 2006]. Available at http://www.cdc.gov./tobacco/global/GYTSintro-htm.

11. Nygaard B, Barfod AB, Hansen FH, Jessen TT, Kryger $\mathrm{H}$, Meyer L. Tobacco, haushis-Knowledge and habits in school. Ugeskr Laeger 1990;152:3540-1.

12. Global Youth Tobacco Survey Collaborative Group. Tobacco use among youth: a cross country comparison. Tob Control 2002;11:252-70.

13. Washington State Department of Health. Tobacco Prevention and Control Program, Progress Report. Washington, 2003. [displayed 19 may 2008]. Available at www.doh.wa.gov/tobacco/program/reports/ TPCPexecsum.pdf 


\section{Sažetak}

\section{PROBLEM PUŠENJA MEĐU MLADIMA U CRNOJ GORI - REZULTATI GYTS (GLOBAL YOUTH TOBACCO SURVEY) ISTRAŽIVANJA}

Pušenje duhana velik je zdravstveni i ekonomski problem, posebno u zemljama u razvoju. Istraživanje je provedeno radi utvrđivanja broja pušača u populaciji učenika osnovnih škola, kao i utvrđivanja stavova, znanja i ponašanja učenika u vezi s pušenjem. Istraživanje o potrošnji duhana kod djece u osnovnim školama u Crnoj Gori provedeno je 2003. godine po jedinstvenoj metodologiji Svjetske zdravstvene organizacije - Global Youth Tobacco Survey (GYTS). Podaci dobiveni istraživanjem pokazali su da u osnovnim školama Crne Gore postoji evidentan problem pušenja, i to već kod djece prije navršene desete godine života. U osnovnim školama postoji 3,6 \% stalnih pušača, dok je jedan od troje (30,6 \%) učenika eksperimentirao s cigaretama. Više od dvije trećine djece koja puše suglasno je da treba prestati s pušenjem, a tri četvrtine njih su pokušavale prestati s pušenjem. Osim toga, istraživanje je pokazalo da djeca malo govore u školama o problemu pušenja, da su osnovci konstantno izloženi utjecaju pasivnog pušenja u vlastitim kućama, kao i izvan kuće. Problem pušenja u osnovnim školama postoji i treba definirati aktivnosti za njegovo rješavanje. Prije svega, treba omogućiti uključivanje preventivnih programa u redovite obrazovne programe u školama, da bi se o problemu pušenja govorilo na adekvatan način. Također, mora se inicirati striktno provođenje "Zakona o ograničenju upotrebe duhanskih proizvoda" da bi djecu zaštitili od pasivnog pušenja.

KLJUČNE RIJEČI: djeca, pasiuno pušenje, pušenje duhana, škola

\section{CORRESPONDING AUTHOR:}

\section{Agima Ljaljević}

Institute of Public Health

81000 Podgorica, Montenegro

E-mail: agima.ljaljevic@ijz.mn.yu 